IP Periodica Polytechnica Civil Engineering

\author{
59(1), pp. 3.7 2015 \\ DOI: $10.3311 /$ PPci.8016 \\ Creative Commons Attribution (1) \\ RESEARCH ARTICLE
}

\section{Gábor Kazinczy and His Legacy in Structural Engineering}

\author{
Sándor Kaliszky, István Sajtos, Benedek A. Lógó, János M. Lógó, Zsuzsanna Szabó
}

Received 14-12-2014, accepted 17-02-2015

\begin{abstract}
2014 is a triple anniversary of Gábor Kazinczy. He was born 125 years ago, his plastic hinge theory was published exactly 100 years ago and he died 50 years ago. This paper is dedicated to his memory.
\end{abstract}

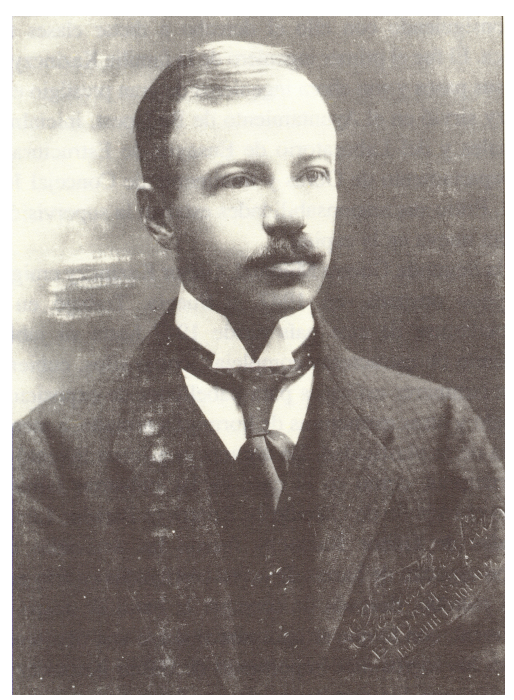

Gábor Kazinczy (1889-1964)

\section{Keywords}

plastic hinge $\cdot$ collapse mechanism $\cdot$ plasticity $\cdot$ reliability analysis and design

\section{Sándor Kaliszky}

Department of Structural Mechanics, Budapest University of Technology and Economics, Múegyetem rkp. 3, H-1111 Budapest, Hungary

\section{István Sajtos}

Department of Mechanics, Materials and Structures, Budapest University of Technology and Economics, Múegyetem rkp. 3, H-1111 Budapest, Hungary e-mail: sajtos@szt.bme.hu

\section{Benedek A. Lógó \\ János M. Lógó}

Faculty of Civil Engineering, Budapest University of Technology and Economics, Múegyetem rkp. 3, H-1111 Budapest, Hungary

\section{Zsuzsanna Szabó}

Faculty of Architecture, Budapest University of Technology and Economics, Múegyetem rkp. 3, H-1111 Budapest, Hungary

\section{Introduction}

2014 is a triple anniversary of Gábor Kazinczy. He was born 125 years ago, his plastic hinge theory was published exactly 100 years ago and he died 50 years ago. This paper is dedicated to his memory. This text is based on the student research work of Lógó et al. prepared in 2014 [22], and Kaliszky's former paper in 2007 [7] and his presentation at the Hungarian Academy of Sciences in 2014 11 Kazinczy's achievements in plasticity and in reliability analysis in structural engineering are among the most important results in this field.

\section{History of his life}

Gábor Kazinczy (Fig. 1) was born in Szeged, January 19 1889; as a great grandson of Ferenc Kazinczy who was a leading contributor to Hungarian literature, an important person in the period of Enlightenment, and he was a reformer of the Hungarian language, too.

He graduated as a civil engineer in 1911 at the Royal Joseph Polytechnic (recently it is called Budapest University of Technology and Economics). He earned his doctor of Engineering degree with a dissertation "Design of clamped end steel beams with regard to the residual deformations" in 1931 [11] and was habilitated and earned the Doctor Habil. title with a dissertation "Safety of structures" in 1939 at the same institution. This gave him the right to lecture at the Royal Joseph Polytechnic (Fig.2).

Gábor Kazinczy served at the Budapest City Council from 1911. First he served as the head of the Material and Structural Testing Laboratory, than as the deputy head of the Urban Development Department in 1932 and finally as Chief Counsellor of Engineering until 1943, when he retired. His duties included the supervision and testing new materials and structures, conducting laboratory experiments and the supervision of the design and execution of new constructions in Budapest.

He participated in study trips to Germany in 1913 and 1924 to study technical inventions and the authority supervision system. At that time, he published ten to twelve papers each year [6, 16, 17]. These papers were basically educational ones, for

\footnotetext{
${ }^{1}$ Memorial Conference of Gábor Kazinczy (1889-1964), Hungarian Academy of Sciences, 12 May 2012.
} 


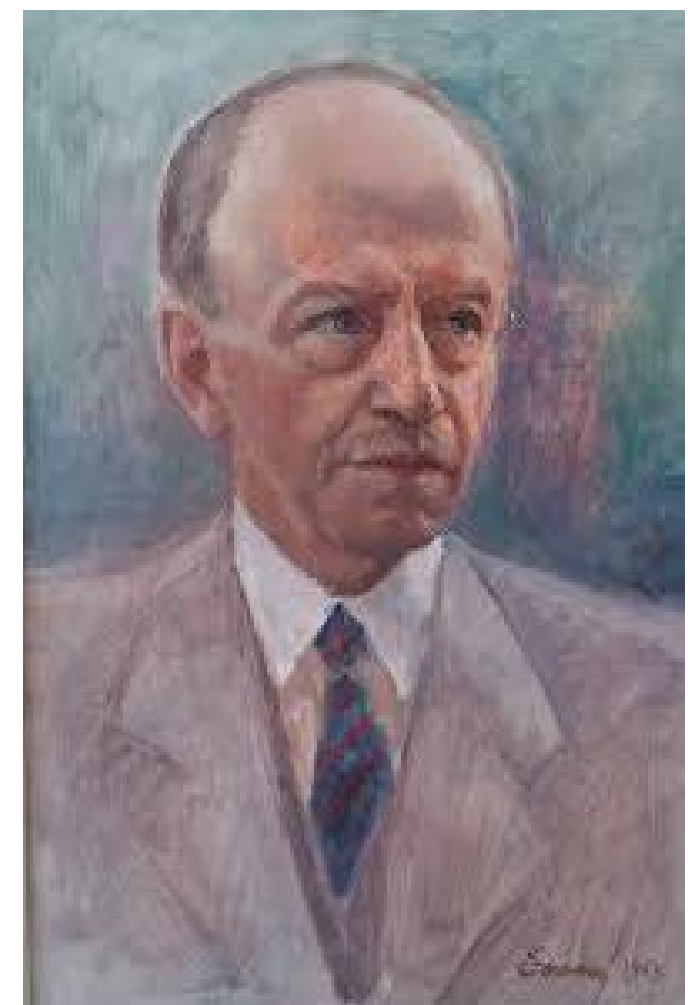

Fig. 1. Portrait of Kazinczy (property of his son)

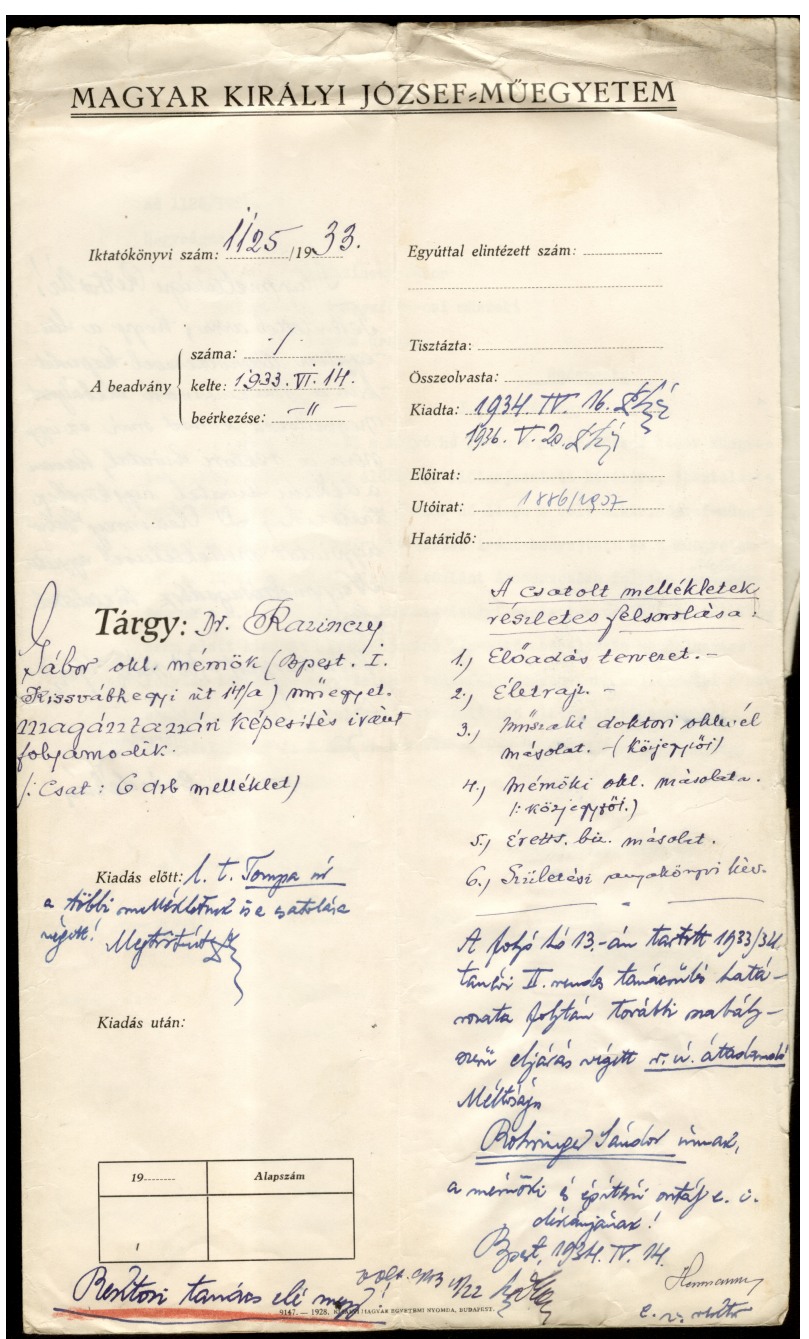

Fig. 2. Application for the Doctor Habil title (1933) (Archives of BME) example, about e.g. behavior of concrete and reinforced concrete, building collapse and about his own experimental results as well. Reading his papers it seems to the reader that he was familiar with both the national and international technical literature very well.

He was also active in the work of both the Association of Hungarian Engineers and Architects and the Material Testing Association.

He took part in the foundation and elaboration of several plastic design methods and the establishment of the Hungarian Design Standard of Reinforced Concrete Structures.

In his private life Kazinczy was an excellent sportsman. Especially he had outstanding results in mountaineering [18] (Fig.3]. In 1926, however, he had a serious accident in the Tatra Mountains (Fig. 4) and as a result of this; one of his legs had to be amputated [10]. In spite of that he remained as active as before and the manner of his life did not change.

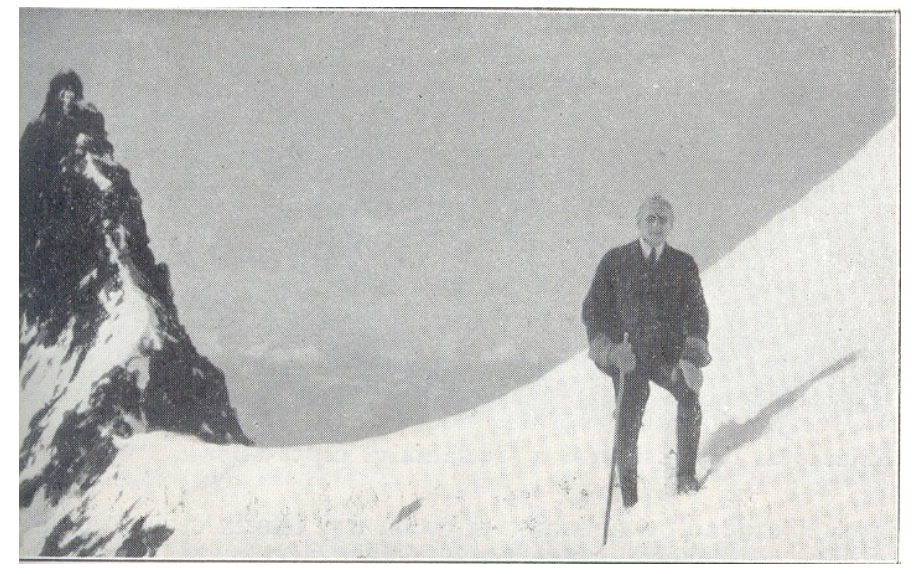

Fig. 3. Gábor Kazinczy at the Tatra mountains [10

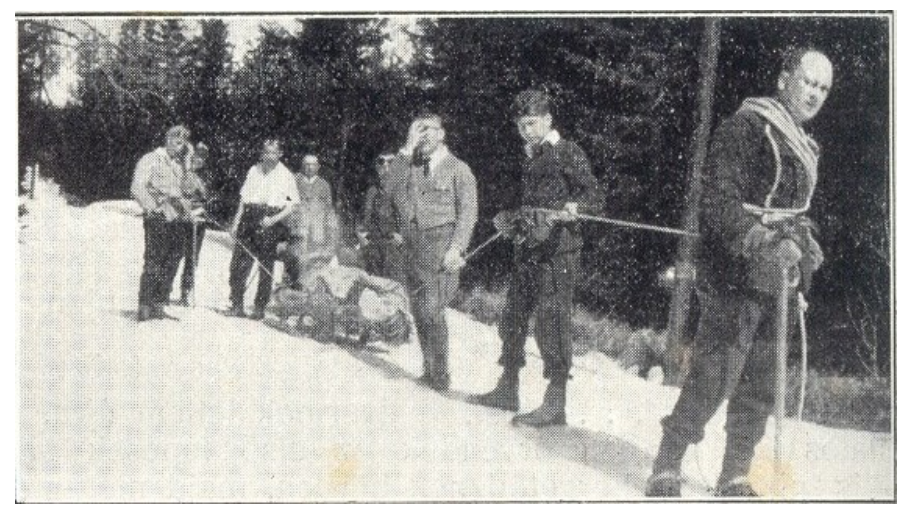

Fig. 4. Expedition for rescue after the mountain accident 10

At the end of the World War II., in 1944, Kazinczy and his family joined to the group of civil and architectural engineering students and professors who were ordered by the government to travel to Germany [24]. Finally they moved to Denmark, where he gave lectures in surveying and in building structures to the students who wanted to continue their studies. In 1947 he and his family moved to Sweden, where he had an oppor- 
tunity to work at the Kooperativa Förbundets Architekt Kontor as a structural engineer up to his retirement in 1959. He was engaged in the design of complicated structures, like large span shells [26 27] (Fig. 5), prestressed concrete floors and other steel and concrete structures. He also worked out new methods of structural buckling as those for cylindrical shells using methods based on the failure theory [15]. Another field of Kazinczy's activities was the patented invention of special cold twisted bars which results in higher steel strength.

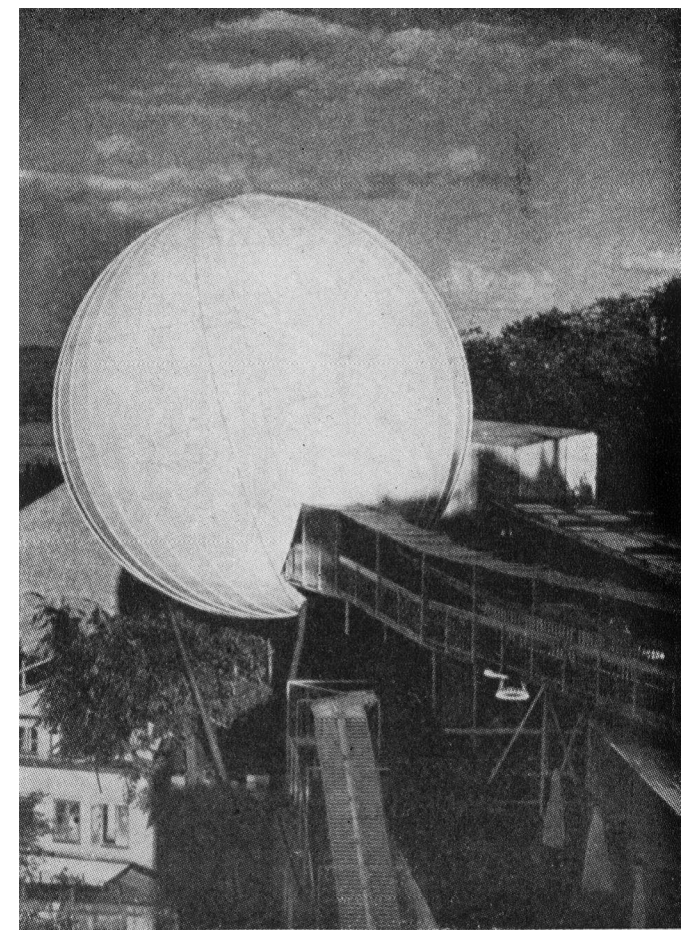

Fig. 5. A building designed by Kazinczy in Sweden 26 27

Kazinczy took part very enthusiastically in organizing the Hungarian engineers and architects living abroad. He was one of the founding members and the deputy president up to his death of the World Federation of the Hungarian Engineers and Architects founded in 1958. (Fig. 6)

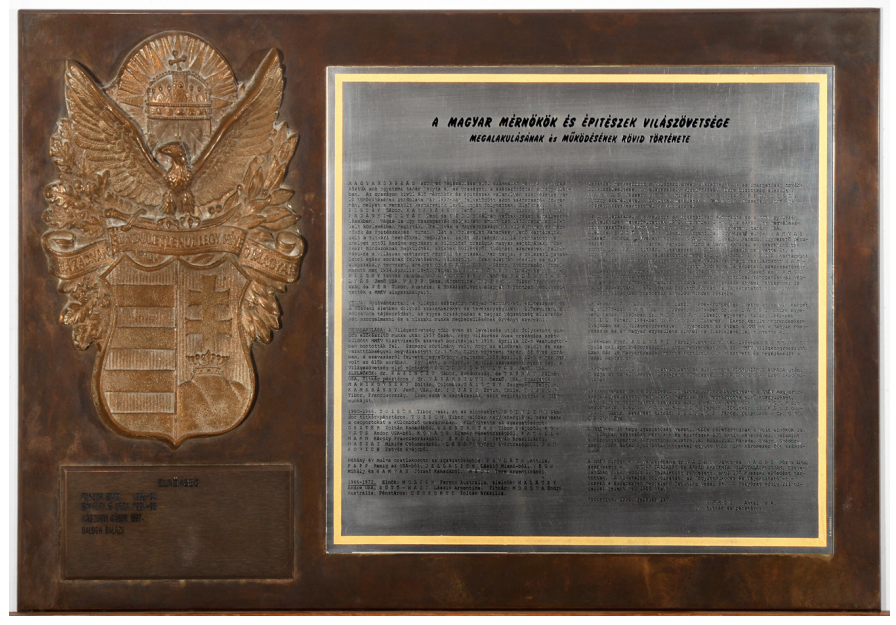

Fig. 6. Plaquette of the World Federation of the Hungarian Engineers and Architects at the Budapest University of Technology and Economics
Kazinczy died in Motala, Sweden in 1964. He was a genius scientist, an outstanding engineer and an excellent person.

His achievements were highly appreciated by other scientists working in the field of plasticity

\section{Kazinczy's scientific results and his legacy}

The most important and most influential achievements of Gábor Kazinczy were the experiments with two, 5.6-meter and 6meter long steel beams embedded in a 1-meter wide concrete slab being part of a floor. The ends of the beams were built in a reinforced concrete beam, which (together with the brick walls above the beams) were parts of a small building being under construction at that time. Considering this arrangement, it was assumed, that the steel beams had perfectly fixed ends (Figs 7, 8).

For loading of the steel beams continuously applied bricks were used. To avoid the development of vaults in the applied bricks $7.0 \mathrm{~cm}$ vertical gaps were left between the brick columns. The load was increased until collapse when the beam sat down on a strong support. During the loading very careful measurement were made. The deflections were measured at 5 points of the beam and the rotations were also registered at the ends. First plastic deformations started to develop at the ends and, before collapse, in the middle. As a result of measurements and observations Kazinczy introduced the concept of plastic hinges. At a point of a beam plastic hinge develops when the moment reaches the plastic moment. In a plastic hinge unrestricted plastic rotations can develop only in the sense of the moment, while after unloading residual deformations remain. Hence the plastic hinges naturally cannot be considered as actual hinges. A beam with fixed ends can undertake large deflections when at three points the moments reach the plastic moment. These places should be considered plastic hinges. If we insert only two plastic hinges in a fixed-end beam it still will be able to carry the load, because the central part "works" as a simply supported beam. If, however three hinges are inserted large deflections start to develop and the beam will collapse. This recognition is the concept of the plastic failure mechanism of a structure. At that time Kazinczy was 25 years old. The concepts of plastic hinges and of the plastic failure mechanism he developed are very important in plasticity.

His results formed the basics of a number of plastic theorems and design methods widely used all over the world. Kazinczy published the detailed description of his experiments in three consecutive issues of Betonszemle (Concrete Review) [8] (Fig. 8) in Hungary in 1914. These papers, however, were not known abroad, because of the Hungarian language and the World War I. Later Kazinczy extended the application of the plastic design method to continuous steel beams with variable loading and on the basis of further experiments with concrete structures also, to continuous reinforced concrete beams [12].

It should be mentioned that N.C. Kist (Delft) in 1917 explained the same concept of plastic hinges and published it in 

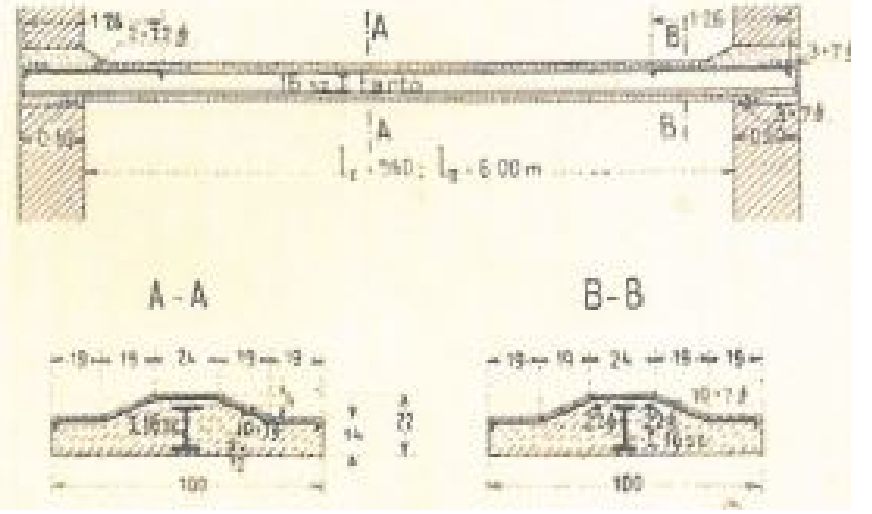

(a)

Fig. 7. Beams used in the experiments and the photo of the experiments [8]
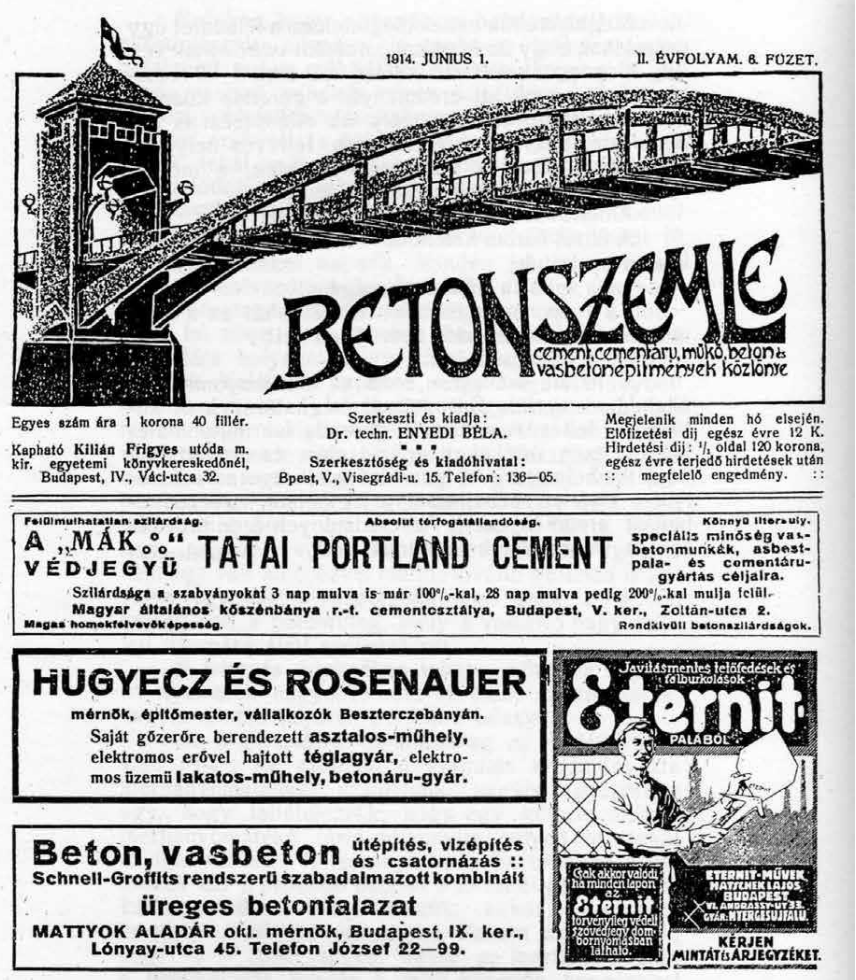

VASBETON éS BETON TaRás EE DARVAS

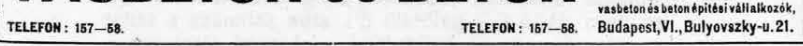

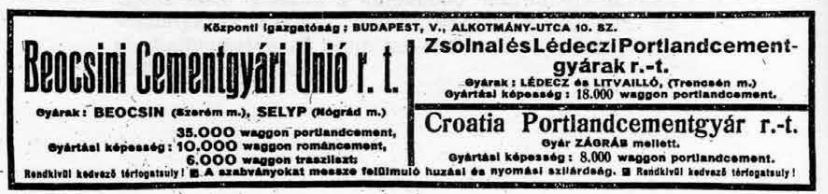

Fig. 8. Front page of the journal Betonszemle $[8]$ (Concrete Review) $\left(1^{\text {st }}\right.$ June, 1914)

1930. H. Maier-Leibnitz (Stuttgart) published the same concept in 1928 and at about this time J.A. Van der Broek published analogous results. Kazinczy's papers were translated only in 1966 [17], 1984 [6] and 2000 [2] to German, to English and to Span-

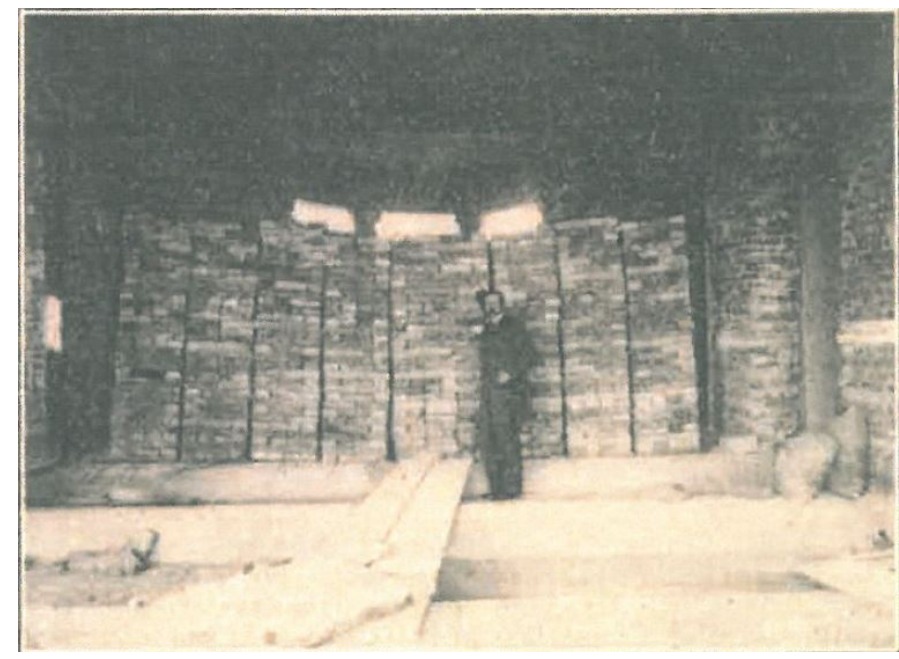

(b)

ish, respectively. In addition to other publications he presented his results with great success in two international congresses in 1928 and 1930. He had a very intense cooperation with several European researchers working in the field of plasticity and took part in the development of the plastic theory and design methods.

There are other fields where Kazinczy conducted significant research. The first is the safety of structures. He was engaged in this field even during the World War I, when the economic aspects of safety problems became more important for him; however these results were published later. His opinion was that the safety against failure of structures should be determined on probabilistic bases and not as a deterministic value. He proposed to take into consideration the uncertainties of manufacturing, material characteristics and load. He clearly understood that the degree of safety at the same time is an economic question, too.

Although his paper about safety was published in 1921 in Hungarian [9], Elishakoff, the world renowned expert of safety credited Kazinczy with first proposing the use of the theory of probability for defining the safety of structures [1].

The other field of Kazinczy's research was the use of plasticity in the case of loads withnot fixed, but changing locations and values and the behavior of statically indeterminate structures as a whole, due to plastic deformations.

Kazinczy also conducted intensive experimental and theoretical research in the strength of bolted connections and cross sections, the load carrying capacity of steel frames, trusses and the residual plastic deformations. His results are summarized in his two books, published in 1942 and 1943 [13, 14].

In addition to his brilliant scientific ability and knowledge, Kazinczy was an excellent engineer, who had a very successful professional activity. He published 92 papers [6].

The importance and priority of his research activity in the field of plasticity was stated and acknowledged in 1936 in Berlin 
during the Congress of the International Association of Bridge and Structural Engineering (IABSE) [25]. This congress initiated the work of J.F. Baker and J. Heyman in Cambridge working on steel frames and W.H. Glanwille and F.C. Thomas in Building Research Station in England working on reinforced concrete frames.

\section{Conclusions}

Kazinczy's achievements were highly appreciated by other scientists working in the field of plasticity [4, 5, 19]. His observations, statements and the foundation of the concepts of the plastic hinges and of the plastic failure mechanisms form the fundamental basis of the plastic design of structures. A great number of calculation methods were developed using the application of the plastic hinges and the plastic design rules suggested by Kazinczy. Because of these achievements and the additional results obtained during his very active researches Kazinczy was one of the founders and the most distinguished and prominent scientist of the field of structural plasticity.

\section{Acknowledgement}

The authors highly appreciate and warmly thank the help and information provided by Ferenc Kazinczy, son of Gábor Kazinczy. The authors are also highly indebted to the Archives of BME, especially to Krisztina Batalka, Budapest City Archives, and colleagues of National Technical Information Centre and Library for the help they provided. The last three authors also thank Mrs. J. Lógó for her continuous encouragement and for the indispensable help they got.

\section{References}

1 Elishakoff I, Safety Factors and Reliability: Friends and Foes?, Kluver Academic Publishers; Dordrecht, 2004.

2 Experimentos con Barras Empotradas en sus Extremos. Experiments with Fixed End Bars., Techn. Inst. of Materials and Constructions (INTEMAC), Infoprint S.A.; Madrid, 2000. (Text is in Spanish, English and Hungarian).

3 Farkas G, Kovács T, Szalai K, A valószínüségi elven történö méretezés történeti elözményei hazánkban. (Historical preliminaries of the design based on theory of probability in Hungary.), Vasbetonépítés, 7(3), (2005), 96-105. (in Hungarian).

4 Heyman J, Structural analysis. A historical approach., Cambridge University Press; Cambridge, 1998.

5 Heyman J, The science of structural engineering., Imperial College Press; London, 1999.

6 Kaliszky S, Gábor Kazinczy 1889-1964, Periodica Polytechnica Civil Engineering, 28(1-4), (1984), 75-76.

7 Kaliszky S, Képlékenységtani kutatások Magyarországon a tartószerkezetek mechanikája területén. (Research in the field of theory of plasticity of structures in Hungary.), Építés - Építészettudomány, 35(2), (2007), 141-158. (in Hungarian).

8 Kazinczy G, Kísérletek befalazott tartókkal. (Experiments with clamped end beams.), Betonszemle, 2(6), (1914), 101-104. (in Hungarian).

9 Kazinczy G, A biztonság fokáról. (On the degree of safety.), ÉpítőiparÉpítômúvészet, 44, (1921), 78-79, 86-87. (in Hungarian).

10 Kazinczy G, A Tátracsúcs. (The peak of mountain Tatra.), Turisták Lapja, 3-4, (1927), 57-64. (in Hungarian).
11 Kazinczy G, Végeiken befalazott hengerelt vasfödém gerendák méretezése a maradó alakváltozások figyelembevételével. (Design of clamped end steel beams with regard to the residual deformations.), PhD thesis, Royal Joseph University; Budapest, Hungary, 1931. (in Hungarian).

12 Kazinczy G, Die Weiterentwicklung der Plastizitätslehre, Technika, 12, (1931.4), 168-172.

13 Kazinczy G, Az anyagok képlékenységének jelentósége a tartószerkezetek teherbírása szempontjából, I. rész. (The importance of the plasticity of materials from the point of view of load-bearing capacity of structures, I. part.), Royal Joseph Technical and Economical University in Hungary,Mérnök Továbbképző Intézet 13. füzet; Budapest, 1942. (in Hungarian).

14 Kazinczy G, Az anyagok képlékenységének jelentôsége a tartószerkezetek teherbírása szempontjából, II. rész. (The importance of the plasticity of materials from the point of view of load-bearing capacity of structures, II. part)., Royal Joseph Technical and Economical University in Hungary,Mérnök Továbbképző Intézet 49. füzet; Budapest, 1943. (in Hungarian).

15 Kazinczy G, Beräkning av cylindriska skal med hänsyn till den armerade betongens egenskaper. (Calculation of the cylindrical shell considering the behavior of reinforced concrete.), Betong, 34, (1949), 239-261.

16 Geleji A, Dr. Kazinczy Gábor 1889-1964, MTA Műsz. Tud. Oszt. Közl. (Hungarian Academy of Sciences.), 34, (1964), 337-341. (in Hungarian).

17 Geleji A, Gábor Kazinczy 1889-1964, Acta Techn. Acad. Sci. Hungariae, 53, (1966), 455-460. (in German).

18 Komarnicki G (ed.), A Magas-Tátra hegymászókalauza. (Mountain climber guide to High Tatra mountains.), Késmárk-Budapest, Turistaság és Alpinizmus Lap-, Könyv- és Térképkiadó RT; Budapest, 1926. (in Hungarian).

19 Kurrer KE, The history of the theory of structures. From arch analysis to computational mechanics, Ernst und Sohn; Berlin, 2008.

20 Lenkei P, Garay L, Experimental Investigation of Limit Rotation in Plastic Hinges of Reinforced Concrete Beams, ÉTI Bulletin, 11(1), (1966), 25-30.

21 Lenkei P, Garay L, Vasbeton tartók képlékeny csuklóinak alakváltozási határai. (Deflection capacity of the plastic hinges of reinforced concrete structures.), ÉTI Tudományos Közlemények, 48, (1965), 1-78. (in Hungarian).

22 Lógó BA, Lógó JM, Szabó Z, Kazinczy Gábor élete és munkássága. (Life and work of Gábor Kazinczy.), Budapest University of Technology and Economics, Faculty of Architecture, 2014. (Student Research Report in Hungarian).

23 Mortezaei A, Plastic Hinge Length of RC Columns under the Combined Effect of Near-Fault Vertical and Horizontal Ground Motions, Periodica Polytechnica Civil Engineering, 58(3), (2014), 243-253, DOI 10.3311/PPci.7329

24 Palasik M, A múegyetemisták odüsszeiája 1944-1946. (Odyssey of students of Múegyetem 1944-1946.), Múegyetemi Kiadó; Budapest, 2006. (in Hungarian).

25 Peters TF, IABSE The First 80 Years, IABSE-AIPC-IVBH ETH Zürich, 2011.

26 Swedish Sphere, 1958, pp. 108, 196.

27 Kazinczy Gábor, Hírünk a világban, Vol. 7, 1958, pp. 9. 